\title{
A Pilot Project on Inclusivity: The Case of the Master of Education Program in Educational Administration at The University of Manitoba ${ }^{1}$
}

\section{ROSA BRUNO-JOFRÉ \& JON YOUNG}

The University of Manitoba

\begin{abstract}
The paper focuses on experiences and developments in one of the volunteer sites of the Inclusive Curriculum Project initiated in June 1993 by the University of Manitoba in volunteer departments and faculties. It deals with the Masters program in Educational Administration in the Department of Educational Administration and Foundations. It opens with an historical background of the debate framing universities' proposals for change and historizing the understanding of academic freedom in relation to equity and inclusivity. In fact, the process generated by the project was by and large conditioned by the dominant set of assumptions about rights, freedom/autonomy. The paper conceptualizes the various responses to the challenges of inclusivity that the Educational Administration group as a whole or as individuals had articulated over time and examined how perceptions and meaning were created, developed and challenged through the dialogue and interventions that took place during the project. In describing the process, the group's concern with evidence is analyzed along with the results of the student survey, and the role of the external "reviewer." It concludes with an account of what was achieved and the thoughts about the politics of the process that was illustrative of the difficulties involved in questioning one's own academic practices and in unveiling relations of power, disentangling one's own system of ideas.
\end{abstract}




\section{RÉSUMÉ}

L'étude se concentre sur les expériences et les développements dans un des sites volontaires du Projet sur l'inclusivité dans le programme d'étude mis en action dans des Départements et des Facultes par l'Université du Manitoba en janvier 1993. Cela traite du Programme de maîtrise en Administration scolaire dans le Département de l'Administration et des Fondements. L'étude ouvre avec le contexte historique du débat qui encadre les propositions de l'université pour le changement, ainsi rendant historique la compréhension de la liberté de l'enseignement par rapport à l'équité et à l'inclusivité. De fait, le processus géneré par le projet a été en grand partie conditionné par l'ensemble dominant de suppositions sur les droits, la liberté et l'autonomie. L'étude conceptualise les diverses réponses au défi de l'inclusivité qu'avaient exprimées le groupe d'Administration scolaire dans l'ensemble ou des individus dans le groupe au course de débat, et examine comment on a créé, développé et mis en question les perceptions et les significantions par le truchement du dialogue et des interventions qui ont eu lieu pendant le projet. En décrivant le processus, on analyse l'intérêt du groupe dans la preuve en plus des résultats de l'enquête sur les êtudiants et le rôle du "critique" de l'extérieur. L'étude conclut avec une explication de ce qu'on a atteint et les pensées sur la politique du processus qui illustre les difficultes impliquées en mettant en question sa propre pratique intellectuelle, en dévoilant les rapports du pouvoir et en se dégageant de son propre système d'idées.

\section{INTRODUCTION}

The public debate about the transformation of higher education reached Canada and The University of Manitoba some time ago. This debate reflects an organic crisis of the university since the very nature of the institution has come into question. There is an urgency to reach points of equilibrium, a new compromise with the various interested parties including the state, the business community, and specifically the university's constituencies. The process calls for negotiation and must take into account the fundamental role of the university as creator of knowledge that goes beyond immediate economic and parochial needs. Inclusivity and equity have had, and still have, a central place in this debate. 
Inclusivity and equity have been addressed at The University of Manitoba by many groups, organizations, committees, offices, and individuals within the University and outside the University. One major institutional effort was a two year Pilot Inclusive Curriculum Project initiated by the University in January 1993. The project was designed to develop and implement gender and racially sensitive curricula and classroom practices. It was a pilot project which worked with volunteer Departments and Faculties and was directed by an Academic Senior Fellow from the Office of the Vice-President, Academic, and Provost.

This paper focuses on experiences and developments in one of the volunteer sites of the Inclusive Curriculum Project at The University of Manitoba namely the Master's Program in Educational Administration in the Department of Educational Administration and Foundations. ${ }^{2} \mathrm{~A}$ small group of faculty members, including the authors of this paper, worked on a review of the program and a critique of their practice with a view to creating a more inclusive program. Jon Young, was at the time Acting Head of the Department and Rosa Bruno-Jofré, Academic Senior Fellow, and member of the Department working in the Foundations area.

The agenda of critical action research embedded in this project was a challenging one. The process we undertook required that all of us within the group subject our practice, our thinking, and indeed our careers to the critical scrutiny of our colleagues and students. The process implied a challenge to the norms underlying academic freedom as commonly understood. Writing about the process provoked participants to ask whether they were engaging in a self-study process or providing data for the authors' research. After completion of the draft we requested our colleagues' opinion. They mostly agreed that our description had successfully captured what the group was trying to do and how the group moved to that end. Regarding the analysis, our colleagues' reactions were more varied. This was not indeed the paper any of them would have written. It is certainly "our" paper and our critical reflections on the process with no claim of "truth." We hope it is insightful and thoughtful within the context of the dual agenda of conceptualizing and actualizing a goal of inclusion and equity within the Department.

In attempting to analyze and theorize about this process the paper seeks: (a) to provide an historical background of the debate framing universities' proposals for change and historize the understanding of 
academic freedom in relation to equity and inclusivity; (b) to use the Educational Administration Master's Program as a case study of some of the complex ways in which faculty members conceptualize, or make sense of, their meanings of educational administration and their roles as professors, thereby defining what constitutes a legitimate curriculum and an appropriate or acceptable pedagogy; (c) to examine the discursive practices and the values and assumptions underlying those practices, the differential relations of power inherent in an alternative discourse, the differential entitlements, obligations, and abilities to participate in the exchange; (d) to conceptualize the various responses to the challenges of inclusivity that the group as a whole or as individuals articulated; (e) to examine, specifically, how perceptions and meanings are created, developed and are challenged through the dialogue and interventions that took place in this project; and (f) to assess what we actually achieved.

Basically this paper considers university departments and other structures not primarily as objective structures of university administration (the formal provisions laid out in the policies of the university), but rather as social constructions, as social, cultural and political sites, and as complex webs of socially constructed meanings and relationships. This perspective is also compatible with the understanding that the concept organizational structure refers to: "the procedures that define the ways in which the organization acts to meet its goals, the technology and activities by which purposes are met" (Chesler \& Crowfoot, 1987, p. 204).

\section{HISTORICAL BACKGROUND: HISTORIZING ACADEMIC FREEDOM ${ }^{3}$}

The organic crisis affecting universities has its roots in social movements, economic pressures and changes in the post-industrial society, in intellectual and ideological transformations and consequent struggles over social meanings, in international political changes, in the shifting of dominant arguments in education from liberal to conservative, and, more recently in developments in high technology. Meanwhile, the debate on the content of the curriculum has centered on the value of the canon, the heritage of humankind as well as on the understanding of civic virtues. The debate emerged out of the struggles of women and minorities for a meaningful role and representation in their education and in public life. 
The questioning of what is taught, the selection, arrangement, and specific content of the curriculum, reached some initial momentum with the strength gained by the civil rights movement and the women's movement both in the U.S. and Canada as well as in many other parts of the world. Notably, various state agencies, especially in the United States, dealt with the discontent of the $60 \mathrm{~s}$ and $70 \mathrm{~s}$ by using force and then by negotiating and accommodating to generate a new equilibrium. The social and educational agencies, including universities, put emphasis on challenging white racism and sexism; the rationale for change was placed, for the most part however, at the level of culture with little or no consideration of issues of power and political economy. For more than two decades, the curricular debate was determined largely by that rationale. During the last ten years there have been important developments in women's studies, Afro-American studies, Aboriginal studies and cross-cultural/anti-racist education that have made clear the need for structural changes, and the understanding of the systemic character of various forms of discrimination.

The university crisis and the curricular debate are also linked to the changes in the capitalist system in its movement towards a postindustrial paradigm. This paradigm has been described by Lash and Urry (Harvey, 1990, p. 175) as disorganized capitalism characterized by its deconcentration of rapidly increasing corporate power away from national markets, internationalization of capital and production, decline of national collective bargaining and the decline of class-based politics and institutions (Harvey, 1990, p. 124). The university crisis is also related to the setting of conservative economic policies and the parallel discourse on higher education. This discourse blames education for economic decline. It largely develops around a notion of accountability which may imply various degrees of interference in internal campus affairs, emphasis on privatization (e.g., industries more able to choose which research to support) and on the application of business techniques to the university setting (House, 1994, p. 29). This approach has the potential to seriously diminish the role of the university as social critic.

There has been a shift in the intellectual configuration that challenges the way of constructing social meanings, of making sense of reality. Perhaps the most relevant change from the perspective of critical social theory is the questioning of the "philosophy of consciousness" that paid 
particular attention to the subject as an agent included or excluded in social practices while neglecting the linguistic impact on the construction of the subject (Popkewitz \& Brennan, 1997, p. 291). The "linguistic turn" moved the emphasis to the systems of reasoning through which the subject is constructed, and focuses historically on pattern relations, organizations of perceptions, and the conception of self. The point made by the authors and others is that when we "use language, it may not be us speaking" nor the speaker defining all the meaning (p. 293). Since knowledge is understood as a material practice it is certainly articulated with other practices and hence the possibility of historizing the conceptions held by academics, in particular, academic freedom.

Popkewitz and Brennan's thesis has interesting implications for the debate around inclusivity in particular in relation to the understanding of academic freedom. This issue of academic freedom is also linked to the notion of authority, expertise, autonomy, and in an open or hidden manner, has been at the core of any process of curricular change. Most current conceptions of academic freedom stress freedom of the professor to investigate, teach, and publish, subject only to scholarly standards and professional ethics. Other restrictions on the choice of research or on the expression of scholarly vicws, whatever their source, violate academic freedom (Eisenberg, 1988, p. 1408; Rabban, 1988, pp. 1431-1439). Historically there have been two overlapping dimensions of academic freedom, on the one hand the rights of the individual academicians within the limits set by professional norms and on the other, issues of university autonomy. Both dimensions are relevant to curricular change in terms of who is dictating change and in terms of adherence to norms regulating academic life perceived as neutral or at best universable.

Two historical examples serve to illustrate the classical conception of academic freedom and provide the parameters for the argument expounded here. One example has to do with the historical contextuality of concepts like freedom, democracy, equality, citizenship, among others. In other words, it has to do with the understanding of statements as social practices that generate actions, as integral part of systems of reasoning through which people construe their roles. When the American Constitution took effect," We, the people" meant we, white males, and our white male posterity. The 1791 Amendment known as the Bill of Rights provided more protection for white males' freedom 
(Leahy, 1994. pp. 447-449). This social contract was based on an ethic of autonomy that did not recognize women, Black people (in slavery), and Aboriginal peoples as participants in the public sphere in part because women and slaves were considered unable to reason and the Aboriginal people were viewed as colonized. The point here is that the original vision was extended and transformed along with the social democratic struggles including the civil war and the women's struggle for political and social rights. Concepts such as freedom must always be contextualized and must be understood fully as social constructions.

The second example deals with the contextuality of the understanding of academic freedom and the functioning of political regimes of truth/systems of reasoning. Most of the definitions of academic freedom drew directly or indirectly from the 1915 Declaration of Principles of the American Association of University Professors on academic freedom. The declaration and subsequent comments make clear that "professors must use the methods and spirit of a scholar" (Rabban, 1988, p. 1409). The immediate question is who defined the methods and the spirit of a scholar? How was this reasoning construed? The point here is that Professor Lovejoy and Professor Sidney Hook, two of the most prominent proponents of dismissing members of the Communist Party during the McCarthy period, used the language of the Declaration in claiming that Communist professors had violated academic freedom, more specifically free inquiry, by reaching conclusions tainted by the party line. The Lovejoy-Hook position prevailed in the academic world during the McCarthy period (Rabban, 1988). Similar arguments were used in some Latin American countries, most particularly Argentina, to purge the university of the so-called subversive elements and feminist women when the doctrine of national security, promoted by the United States, was implemented in the 1970s. These attacks were carried out in the name of scholarship, standards, ethics, political bias, ideological bias. Feminist scholars, scholars from the third world, scholars of color, gays and lesbians, and other subordinated groups who create self-defined knowledge still have difficulties, because they expand the classic discussion of academic freedom to question ways of perceiving, ways of reasoning, paradigms, in a different way. They pose questions such as: "Why are we asking only this one question," a narrowness that led to the preeminence of specific discourses and paradigms (Morgan, 1995, p. 29). Women 
became "epistemological heretics" to borrow Kathryn Morgan's expression (p. 33). As it happened in McCarthy's time the limits to professional autonomy were set by adherence to unquestioned professional norms and we need to make them problematic. When the mechanisms to secure academic freedom were set, the American university was an exclusive place. The parameters of academic freedom as established through the understanding of expertise, peer reviewed publications, definition of scholarship were set by white middle class men. The understanding of academic freedom and equity/inclusivity as contradictory solitudes represents an incongruence in academic life. This incongruence is implicit in the often expressed assumption that equity and inclusivity embody a threat to academic freedom and to the integrity of research.

However, if the university's obligation is to search for knowledge, inclusivity makes sense from an epistemological perspective. The already classical breakthrough by Gilligan (1982) in the area of moral development is still a good example. Lawrence Kohlberg's stage theory of moral development, that presumed to be universal, was taught for many years without much concern for the fact that women seemed to fall on a stage below men. The way Gilligan challenged Kohlberg's assumptions is instructive. She did not simply present a moral dilemma to the subjects of her research, but instead she asked what a moral dilemma was. She asked questions to know when a situation took on moral significance for the girls and boys. She asked boys and girls what morality was. In light of these questions Gilligan perceived two voices, one that had been silenced, the other that had been legitimized in Western thought (Kasprisin, 1991). Women biologists such as Bleir, Fox Keller, Rose, Harding, etc. have become highly critical of contemporary biological theory and the inadequate treatment of questions involving sex, gender, race, and class. Many of them have pointed out "the devastating and lethal consequences" of biological theorizing and medicine based on exclusion (Morgan, 1995, p. 30).

The rethinking of established knowledge goes hand in hand with the rethinking of the basic systems of thought regulating universities. In the process of curricular change and review of the teaching-learning processes, academic freedom appears expressed in relation to requests for evidence of lack of inclusion (or of unequitable situations), to claims of expertise, and free choice within scholarly parameters. The Pilot 
Project on Inclusive Curriculum at The University of Manitoba and in the Department of Educational Administration and Foundations tried to make problematic and rethink academic freedom and related notions of universal fairness in an attempt to initiate an agenda that would move us toward a more equitable and inclusive institution.

\section{THE DEPARTMENT OF EDUCATIONAL ADMINISTRATION AND FOUNDATIONS}

The focus of the project described in the rest of this paper was the Master's Degree program in Educational Administration based within the Department of Educational Administration and Foundations (which also houses a small Adult Education program).

Although almost all of the students are part-time and take around 4-6 years to complete their program, the Master's program is normally described as a two year, 48 credit hour program. Included in it are 12 credit hours of Foundational Studies (Sociology of Education, Philosophy of Education, History of Education in Manitoba, and Theoretical Perspectives in Educational Administration); 12 credit hours of Specialized Educational Administration courses; 6 credit hours of Research Methods, a number of Elective courses, and either a thesis or a comprehensive examination.

Throughout the duration of the project, approximately a year and a half during 1992 and 1993, the Educational Administration Faculty Group met regularly and consisted of the four Educational Administration male professors, who regularly taught most of the specialized educational administration courses, and one female professor from the Foundation area who, as Senior Academic Fellow responsible for a University-wide initiative on Inclusive Curriculum, played a central role in initiating and sustaining the whole process. The interactive process of these five academics is of primary interest in this study.

Among the characteristics of the Group several appeared particularly salient to our understanding of the process of change as it evolved in relation to this inclusivity project. First, like most of the professorate in Educational Administration the group was predominantly male, made up of middle-aged white men. ${ }^{4}$ The only female member of the group taught primarily in the Foundations area. Second, all members of the group had 
a longstanding interest in issues of equity, albeit with quite different foci, from Aboriginal education, multicultural and anti-racist education, gender studies, as religion and education. They also brought different ideological orientations to the Group. Not all members had similar concerns with the integration of the analysis of race, gender, class, ethnicity, sexual orientation, and body ableness. There was some fragmentation grounded in notions of expertise and personal interest.

Third, the four men of the group shared, in their view, a strong sense of collegiality and energy that had been built over time. While the two senior members of the group had been in the Department some 20 years the other two and the female member had been together some 5-8 years. This sense of collegiality was assumed to be extended to the female colleague within the context of an interactional code that nonetheless tended to suppress the difference she could bring to the group. Each member, except for the female one, had worked collaboratively and written collaboratively with at least one other member of the Group. Collegiality as described here often did not equate with easy consensus within the male group or in interaction with the female colleague. Nor did it limit the struggle for control of the agenda in order to frame the discussion of inclusivity. Power configurations constrained the discursive practice. The female faculty felt often positioned in a differential relation of power and, in spite of her being the Academic Senior Fellow, had to continually struggle to claim her space.

The decision to make this group of faculty and the Educational Administration Master's program the focus of this change process was made quickly after the Department Council voted to be a site for the study within the overall university Inclusive Curriculum Project. It was based upon two key strategic issues of control and commitment. In choosing to focus on the graduate program rather than all or part of the undergraduate program the Acting Head of the Department and the Academic Senior Fellow chose to work with a program over which the Group collectively exercised a considerable degree of control. Choosing to limit the attention to the Educational Administration Master's degree was another strategic decision. It was based on the perceived degree of common understanding and commitment to exploring the issues. 


\section{THE PROCESS}

Over the course of the 1993-94 academic year the project took on a variety of different activities. However, the central unifying element was the monthly Group meetings that the Group members committed to holding, a commitment which was observed with considerable fidelity. It was at these meetings that the Group struggled to establish a shared understanding of inclusivity and its relevance and application to the Educational Administration graduate program. Out of these discussions came other Group activities: a survey of our graduate students past and present and a review of our program by an external colleague conversant with inclusivity issues; the development of a new pilot course; the preparation of a series of recommendations for Departmental Council, as well as individual activities.

\section{GETTING STARTED: BEGINNING TO DEFINE INCLUSIVITY AND MAKE IT OPERATIONAL}

Each member of the Group brought to the discussions her/ his particular understanding of and commitment to issues of equity, justice and diversity. There seemed to be no shared understanding of the concept of inclusivity nor of what an inclusive graduate educational administration program might look like. The struggle to establish these meanings for the Group was by and large what the project was about and it reflected the attachment to well established ideas about academic freedom and professional autonomy as a basis to deal with inclusivity. The group did not have a model to look at in terms of an inclusive project in administration but there were enough models in other fields emerging from the American projects and syllabi to examine. Furthermore, the setting up of a Clearinghouse on Inclusive Curriculum facilitated the process of acquiring materials. The Group, however, made limited use of the Clearinghouse. ${ }^{5}$

On the one hand, there was concern that the Group might follow the so-called "party line," in particular a radical feminist agenda that could be imposed upon the group and the students. On the other hand, there was considerable discomfort with the lack of a well defined concept of inclusivity but also resistance to depart from intellectual constructions such as clarification of the concept in light of other inclusive projects. The Group tried to frame the discourse and to assert its own definition of inclusivity 
in light of the administration program. Theories of leadership dealing with caring and nurturing became important point of reference. When disagreements emerged, the group tended to revert to areas of previous agreement. It appeared to be easier to arrive at agreement on many of the elements of an inclusive program than it was to arrive at consensus on the reconceptualization of the program as a whole. A fragmented approach was less threatening to individual entitlements and ways of doing things.

These negotiations were not simply an intellectual process of developing meanings. They also tended to become political as individuals and groups of individuals struggled to have specific meanings, priorities, and agendas accepted as "common meanings" or perhaps more correctly as group sanctioned meanings. Some degree of consensus was obviously necessary to avoid individual faculty retreating to a practice of isolationism and individualism. Within the ideological context described above, the following questions acquired a central place in the process: "What was the problem here?", "Whose evidence should be accepted that a problem exists that requires the Group to think about and to do things differently?", and, finally, "Whose responsibility should it be to get things done differently?"

While recognizing the intersection of sex, gender, race, class (heterosexism was not readily discussed), gender issues provided a starting point for the discussions. An existing feminist literature in educational administration with which the Group was at least partly familiar added to the appeal of such an initial focus. At its first meeting, on September 10th 1992, the Group made an initial effort at naming the focus of the project. It was acknowledged that the Educational Administration program was staffed primarily by white male professors and that without injection of funds and the will to hire a woman faculty member, that situation could stay for another ten years. Three questions became a pragmatic statement of the project and provided an initial focus: "How did students feel about the relevance of inclusivity?" "How did they feel in the classroom and in the Department?", and "What might we be doing to change this situation if necessary?" These questions provided a comfortable space allowing the members of the group to have a frame of reference to deal with fundamental issues of autonomy in their own terms. 


\section{WHAT IS THE "PROBLEM"? - MEANING AND LEGITIMACY}

The process of curriculum transformation generated tensions by challenging professorial entitlements, breaking routine patterns and dislodging situational power. It forced members of the team to open to scrutiny the content of the courses they taught and the methods they used to teach. There were also pressures on participants to do things differently, requiring effort not only in terms of reworking their practices but also in terms of psychological energy to re-examine the value base of their work. Furthermore, such discussions had the potential of disrupting existing relationships and statuses within the group. Such tensions may to various degrees be ameliorated or 'managed' but they are unlikely ever to be completely avoided.

Drawing on the work of Lynch (1986), McIntosh (1983), and Patricia Hill Collins (1991) among others, we, the authors of this paper, try to conceptualize the responses to the challenges of inclusivity. This conceptualization seeks to capture the range of perspectives that might be manifested in specific contexts and in relation to specific elements of inclusion by the group as a whole and by individuals within the group. The point of departure here was the personal experience of Group members.

\section{The courses beyond gender, universalizable paradigms, and the instructor knowledge base}

In as much as the discussions focused upon curriculum content and drew upon the existing literature within educational administration, the centrality of different aspects and issues of inclusivity were less unproblematic in some courses and areas of the program than in others. For courses such as "Educational Administration as a Field of Study and Practice," "The Politics of Education," or "Theoretical Perspectives in Educational Administration" connections were generally more apparent and wide ranging than in courses such as "School Law," about which there were questions such as "What is inclusive law?" There was an argument that the issues were beyond gender, race, ethnicity and throughout there was the requirement of proof.

The question of construction of knowledge beyond gender or race, and the related assumption that there are universalizable paradigms are linked to whether faculty members acknowledge or not the need to 
rearticulate knowledge and reconceptualize the field. Within the Group, one of our colleagues expressed a great concern for the place of expertise and the need to do what he knew well. "What is it," "I don't do it," "I need to do what I'm good at...I need to change." Since the Group was aware of his strong commitment to the students, these questions raised the issue of institutional support-illustrating clearly to us that the process of changing curriculum implies time and resources.

Patricia R. Schroeder in Reconstructing American Literature: An Ongoing Process addressed this point when she wrote:

Revising the canon poses new challenges in the classroom beyond mere syllabus reconstruction. What in the world do you talk about when your class reads noncanonical literature in perhaps nontraditional forms, and you haven't spent eight years in graduate school studying it? Constructing creative solutions to this problem has provided me with some of my most rewarding classroom experiences, despite the pre-class panic I sometimes feel. (p. 12)

Morgan lists among what she calls "dangerous equivocations," "the equation of "qualifications" and "expertise." In her view unproblematized reliance on credentials creates "justifiable" grounds for exclusionary practices (Morgan, 1995, p. 29). This equivocation is part of what she considers "dubious dualisms" such as universality and particularity, expert and amateur, rationally justified truths and social justice and transformation (Morgan, p. 31). Expertise should be critically explored when dealing with inclusivity. Morgan points out the danger of denying relevance, in the name of universality, to standpoints which embody epistemic particularity, for example, gender related or based on the lived experiences of Aboriginal Peoples or Afro-Americans. Morgan maintains that it is important to problematize universality as an epistemological ideal.

\section{The enabling approach/orientation: Accommodating students' needs}

This orientation, while silent on the responsibilities or commitment of the program to make inclusivity a focus of what is taught, did provide some space for students to explore for themselves select issues of inclusivity (although most often without a conceptual framework grounded in educational administration). The presence of colleagues from Women's 
Studies and feminist specialists from other Faculties in the students' advisory committees brought into the Department of Educational Foundations and Administration alternative paradigms and expanded the knowledge base of the faculty members involved.

Within the Department a considerable number of Master's (as well as some Ph.D.) theses have focused on equity topics, and while some have clearly been 'sparked' and nurtured by instructors and by course content others have drawn their primary inspiration and direction from sources outside of the Department. One of the comments written by a female student who responded to the survey conducted with graduate students in Educational Administration captured a general tendency of the program:

Although inclusivity is mentioned in courses, there are only a few ( 2 or 3 ) courses that actually study the concept in its own right! Therefore, in designing course work, a conscious attempt must be put forward to include at least one specific lecture and/or assignment in this area. This would also include 'readings'.

\section{Inclusivity as a topic}

This third orientation/perspective resembles a mix of McIntosh's phases three, "women as a problem, anomaly, or absence," and four, "women on their own terms" in the sense that there is a recognition that women as a group are not in the curriculum and that it is necessary to include their experiences and perspectives in educational administration. Issues of inclusivity and equity are parceled off within particular courses in the form of a "topic" in educational administration, a "recent development" or "one of several emergent theoretical perspectives." Issues of inclusivity and equity are sometimes recognized as a body of knowledge to which students either should (required course) or might (elective course) be introduced. In the latter case students may take courses in Women's Studies, Native Studies, or in any other Department. This orientation may easily lead to what Morgan calls "pseudo-inclusion," because the inclusion involves the appropriation, exploitation, and the explicit denial of originary epistemic subjectivity of women and men of color and members of other systemically excluded groups" (1995, p. 33). 


\section{Systemic Integration/Programatic Focus}

This orientation is close to McIntosh's "reconstructed knowledge." Its implementation would articulate an over-arching framework for thinking, talking, and doing in the educational administration program that takes into account gender, sex, ethnicity, race, class, sexual orientation. Systemic integration aims at decentering the curriculum and the program by integrating epistemologies that come from the knowledge and standpoints of previously excluded groups (Collins, 1991). Not being confined to curriculum content, pedagogical, climate, university structure, and personnel would be seen as equally important issues. The statement in the Departmental brochure attempts to provide a tentative basis for this orientation, an orientation that was never fully embraced. It reads:

Inclusivity is a goal and a central theme for the Master's Program in Educational Administration. We believe that our materials, pedagogy, and policies should provide for the authentic presence of multiple perspectives and voices in Educational Administration, including feminist perspectives and the Perspectives of Aboriginal peoples of Canada. ${ }^{6}$

While the work of the Group over the year and a half served to make inclusivity a more explicit and coherent theme for its members, the program remains, perhaps like most other graduate programs, a largely fragmented package of courses. The limits to change were set by both the resilience of well established frames of reference regarding the role of the scholar, her/his entitlements, and by structural constraints.

Not only is inclusivity not the unifying theme of the program, there is no unifying theme in the program. When the current program was designed some nine years ago the Department was committed to integrating the Foundations and Administrations areas, not primarily because of the pragmatics of having the two areas placed geographically and administratively together, but because the members of the Educational Administration area shared a common view of Administration as a moral, ethical, political and educative process that necessarily rested upon a Foundational basis. The result was a program that included a four half course "Foundational Core" and an Introductory course, Educational Administration as a Field of Study and Practice that sought to lay out this perspective on Educational Administration. In 
addition there was a Departmental commitment to work toward the integration of the two content areas. For example, the Department offered a Law and Ethics Summer Institute and History of Education was designed in relation to Politics of Education. However, several factors contributed to the fact that integration has been limited. Students may and do take the introductory courses at any point in their program. Many, especially part time graduate students, take the bulk of their courses over summers with sessional instructors. As the results of the graduate survey undertaken clearly indicated different students experienced the program in quite different ways depending on the courses they chose, the sequence in which they took their courses, and the instructors they had for them. The students' observations in relation to inclusivity and the program in general made clear the need for a plan of action.

\section{WHAT IS THE EVIDENCE?}

The concern with evidence shows the limits to the understanding of systemic integration and reconceptualization of the academic enterprise including our entitlements as professors. There was suspicion of an alledged radical feminist agenda. It was necessary to show that our students were not happy with the program as it was.

Early on in the Group's discussions of "how we might do things differently" and "whose definition of the situation would become the group sanctioned definition," the issue of what could/should/would constitute appropriate "evidence" surfaced as an important issue, expressed, for example, in the following observations among the group:

I am much more interested in addressing seriously problems that our students identify with our curriculum and our behaviours than I am in holding an ideological mirror up to our practice.

We need to start with systematic and neutral inquiry into our students experience. We need to ask whether is there something that happened here which makes them feel left out, excluded or on the positive side brought in. (Meeting of November 4, 1993).

These questions and concerns had deep roots. The Group as a whole did not deal with the outpouring of critical analysis of Western science, 
technology and epistemology specially, from a feminist perspective. Some members of the Group expected that women would be fully aware of their own subordination if there was any and assumed that students would know what is absent (race, ethnicity, gender, etc).

The Group dealt with concerns in a number of different ways: they discussed and debated, in a limited manner, some of the literature on inclusivity within universities and within educational administration. They considered materials from other Canadian universities. There was, however, reluctance/resistance to working with what was construed as external agenda and supervision. Again this is an issue of academic autonomy/freedom. There was also resistance to an external evaluation/ assessment. Two of the main activities undertaken by the Group to provide the "evidence" were (a) a survey of our graduate students, and (b) a visit and 'evaluation' of the program by a female colleague from another university.

\section{THE STUDENT SURVEY}

The inclusion of students' voices in the process of self-study was generally recognized as being of central importance. Unfortunately, the basic mechanism of the review that was chosen, the Area Group Meetings, did not encourage any direct student participation. The Group agreed to undertake a survey of student experiences within the Department. (Please refer to Appendix 1.)

After some initial discussions of the format and substance of the survey a short, semi-structured, fifteen item questionnaire was designed and mailed in January 1994 to a total of 123 students either currently registered in the Masters program or recent graduates from it. The questionnaire was divided into five sections dealing with: Program Content; Teaching Methods/Classroom Interactions; General Departmental Climate; General Comments, and Personal Demographics. Of the 123 questionnaires mailed out, seven were returned because the person no longer lived at the address used, and a total of 52 completed questionnaires were received and analyzed (see Table 1).

Of the 52 questionnaires that were received 37 were returned by female graduate students and 15 by male students, representing a female response rate of $54 \%$ and a $27 \%$ male response rate. Without reporting on all of the data from the survey (Bruno-Jofré \& Young, 1994), Tables 2 to 5 
Table 1

\section{Responses by Gender}

\begin{tabular}{lccc}
\hline & $\begin{array}{c}\text { Students } \\
\text { in Program }\end{array}$ & $\begin{array}{c}\text { Questionnaires } \\
\text { Returned }\end{array}$ & $\begin{array}{c}\text { Response } \\
\text { Rate }\end{array}$ \\
\hline Female & $68(55 \%)$ & $37(71 \%)$ & $54 \%$ \\
Male & $55(45 \%)$ & $15(29 \%)$ & $27 \%$ \\
Total & $\mathbf{1 2 3 ( 1 0 0 \% )}$ & $\mathbf{5 2 ( 1 0 0 \% )}$ & $\mathbf{4 2 \%}$ \\
\hline
\end{tabular}

summarize responses to those questions that referred to student experience of the program as a whole. The data in these Tables, we suggested, indicated that: students generally appeared to have quite widely differing experiences in the Educational Administration program depending upon the courses they took, when they took them and who taught them, as well as on the expectations that they brought to their programs. Furthermore there appeared to be some quite distinct differences in the ways in which women and men experienced the program and life in the graduate classroom.

Inclusivity was seen to be "very important" to more than half of the women responding to the survey and slightly less than one-quarter of the men (Table 2). While there was general support for the statement that inclusivity in all courses was important, this was expressed more strongly by women students. For a proportion of both male (14\%) and female students $(8 \%)$ the issue was seen as unimportant.

When asked how adequately their courses to date had involved the work and experiences of Women, Aboriginal Peoples, and Minority Ethno-cultural groups (Table 3), male responses were again more positive than the female responses. In Tables 4 and 5 a distinction was made between the extent to which the program allowed students to develop a knowledge of issues of inclusivity as distinct from requiring that they develop this knowledge as a central part of their course work. Student responses summarized in Tables 4 and 5 suggested that we do better in allowing and supporting student interests in inclusivity than building it into the core requirements of the program.

The survey provided the Group with some important "evidence" both in terms of the quantitative tables that were produced and the 
Table 2

Question 1: How important do you feel it is that all courses in the program include material that involves and affects Women, Aboriginal People, and Minority Ethno-cultural Groups?

\begin{tabular}{lrrrrr}
\hline & $\begin{array}{c}\text { Very } \\
\text { Important }\end{array}$ & Important & $\begin{array}{c}\text { Quite } \\
\text { Important }\end{array}$ & Unimportant & \multicolumn{1}{c}{ Total } \\
\hline Female & $19(51 \%)$ & $12(32 \%)$ & $3(8 \%)$ & $3(8 \%)$ & $\mathbf{3 7 ( 1 0 0 \% )}$ \\
Male & $3(21 \%)$ & $8(57 \%)$ & $1(7 \%)$ & $2(14 \%)$ & $\mathbf{1 4 ( 1 0 0 \% )}$ \\
Total & $\mathbf{2 2 ( 4 3 \% )}$ & $\mathbf{2 0 ( 3 9 \% )}$ & $\mathbf{4 ( 8 \% )}$ & $\mathbf{5 ( 1 0 \% )}$ & $\mathbf{5 1 ( 1 0 0 \% )}$ \\
\hline
\end{tabular}

Table 3

Question 2: How adequately do you feel that the courses you have taken to date have involved the work and experiences of Women, Aboriginal People, and Minority Ethno-cultural Groups?

\begin{tabular}{|c|c|c|c|c|c|}
\hline & Very & & Quite & & \\
\hline & Well & Well & Poorly & Poorly & Total \\
\hline Female & $1(3 \%)$ & $17(53 \%)$ & $11(34 \%)$ & $3(9 \%)$ & $32(100 \%)$ \\
\hline Male & $3(21 \%)$ & $7(50 \%)$ & $2(14 \%)$ & $2(14 \%)$ & $14(100 \%)$ \\
\hline Total & $4(9 \%)$ & $24(52 \%)$ & $13(28 \%)$ & $5(11 \%)$ & $46(100 \%)$ \\
\hline
\end{tabular}

Table 4

Question 3: How well do you feel that the program has allowed you to develop your knowledge of issues of inclusivity in Educational Administration?

\begin{tabular}{|c|c|c|c|c|c|}
\hline & Very & & Quite & & \\
\hline & Well & Well & Poorly & Poorly & Total \\
\hline Female & $6(18 \%)$ & $15(45 \%)$ & $9(27 \%)$ & $3(9 \%)$ & $33(100 \%)$ \\
\hline Male & $5(33 \%)$ & $8(53 \%)$ & $2(13 \%)$ & -..- & $15(100 \%)$ \\
\hline Total & $11(21 \%)$ & $23(52 \%)$ & $11(21 \%)$ & $3(6 \%)$ & $48(100 \%)$ \\
\hline
\end{tabular}


Table 5

Question 4: How well do you feel that the program has required all students to become more knowledgeable about inclusivity in Educational Administration?

\begin{tabular}{lccccc}
\hline & Very & \multicolumn{4}{c}{ Quite } \\
& Well & Well & \multicolumn{1}{c}{ Poorly } & Poorly & \multicolumn{1}{c}{ Total } \\
\hline Female & $2(6 \%)$ & $9(27 \%)$ & $16(49 \%)$ & $6(18 \%)$ & $\mathbf{3 3}(\mathbf{1 0 0} \%)$ \\
Male & $4(27 \%)$ & $8(53 \%)$ & $3(20 \%)$ & --- & $\mathbf{1 5 ( 1 0 0 \% )}$ \\
Total & $\mathbf{6 ( 1 3 \% )}$ & $\mathbf{1 7 ( 3 5 \% )}$ & $\mathbf{1 9 ( 4 0 \% )}$ & $\mathbf{6 ( 1 3 \% )}$ & $\mathbf{4 8 ( 1 0 0 \% )}$ \\
\hline
\end{tabular}

anecdotal comments compiled from the open-ended questions included in the survey. These data were not presented as an unambiguous assessment of our program and its strengths and weaknesses. Each set of data was open to a quite lively interpretation as to its meaning, significance and implications as another part of the group's ongoing struggle to develop meanings and strategies. The survey, in spite of its limitations, did however provide an important input into our group discussions as well as student input, and a number of concrete suggestions as to how we might to do things differently. The point was to inform our discussions rather than to be "the perfect questionnaire." Perhaps the most contentious issue when even dealing with the informal interpretation of the questionnaire was the possibility that an overall positive response could serve to downplay the importance of the need to do things differently.

\section{THE EXTERNAL VISIT AND REVIEW}

The group agreed to invite a female colleague to review outlines and syllabi and to meet with members of the Educational Administration Group and graduate students. After a two day visit with the Department she prepared a two part report in which she made general comments and recommendations and provided very useful bibliographical references to work toward the transformation of the curricula in educational administration. Our guest suggested that the "syllabi should legitimate a wide range of personal and professional experience 
as contributing to the construction of knowledge." She urged the group (a) to expand the use of materials to bring a variety of voices and multiple perspectives on issues into every course and suggested ways to do that; (b) to legitimate differences among women, to acknowledge that there is no one feminist perspective; (c) to build that into the readings; (d) to recognize that providing more perspectives on any one course topic/issue means reducing the number of topics or issues to be addressed; (e) to review existing course syllabi with respect to their 'tone'," making them more inviting by clarifying that some aspects of the course are more flexible or negotiable than what was indicated; (f) to use an inclusive language and discuss the rationale for its use.

With reference to teaching practices the reviewer encouraged the group to (a) seek out and involve more women as guest speakers and course instructors; (b) attend to the interactive process in class work "to create or protect space for more tentative or minority voices and viewpoints; (c) recognize that introducing and "creating space" for differing perspectives will meet resistance from some of the students. She acknowledged that being respectful and encouraging others to be respectful of differences, without giving up all hope of critical discussion, is not an easy task.

The reviewer recommended that the group develop a collection including books, articles, non-academic writings, videos, alternative experiential and analytical perspectives; and made the point that faculty members be encouraged to use the Clearinghouse on Inclusive Curriculum that had been established as part of the Inclusive Curriculum Project. The reviewer echoed comments from the students to seek out more women faculty. She wrote: "No matter what efforts toward equity and inclusivity male professors make, there are always some constraints associated with cross-gender dealings, especially when students' personal circumstances may be impinging on their academic progress or success." She advised the Department to document hiring opportunities and develop policies and practices regarding hiring and renewal of term teaching contracts, awards of teaching or research assistantship with male/female breakdowns.

The reviewer became very much aware of concerns regarding resistance to inclusivity of some students in the classroom, and its impact on the monitoring process such as evaluations by them that are later used in 
the tenure and promotion process. As she pointed out, some graduate students carry over to the classroom considerable authority (seen within the Group as actual power) from their professional paid-work positions, and will also sometimes bring with them sexist biases.

The visit provided legitimization to the process of self-review. The Group had wanted a person whom they knew and with whom they felt comfortable. The visitor had worked collegially with several of the members of the area group. Conceptually the Group worked out at the time a broad understanding of inclusivity which did not fully agree with the view expressed by the Academic Senior Fellow and others on campus that faculty needed to rethink courses, reconceptualize them, and deal with the idea that epistemologizing is a political act.

The tendency shared by some members of the group, and by the reviewer, to downplay the instructor's authority and the emphasis on giving equal weight to all voices had the potential to inhibit critiques of injustice and subordination, including the standpoints of subjugated knowledge. As Carmen Luke (1996) has pointed out this approach risks access under the pretense of equal subject positions. It is a matter of differential power. Furthermore, "we all know that male instructors can approach issues of inclusivity without dealing with the kind of resistance women encounter." Voice of the Caucus, 1 (March 7, 1994).

A loose non-normative understanding of inclusivity has implications for teaching that feminist pedagogues neglected until recently. Those of us who taught from a feminist perspective knew that to contest the canon we have to appeal to normative discourses. This appeal raises the issue of authority at the level of discourse and discursive practice (Luke, 1996). Jones (cited by Luke, 1995) articulated the central problem:

... Feminists are confronted with a paradox: claiming that authority is the practice most necessary for all women - and all "others". . . while simultaneously deferring the question of writing [and speaking] authoritative texts in favor of a theoretical position supporting a veritable cacophony of voices. I contend that we remain trapped in and immobilized politically by a peculiar discourse on Authority. (p. 295)

In spite of the theoretical observations, we, the authors, acknowledge that a more critically defined approach would have been difficult to pursue. The report written by the external reviewer was very useful and 
viable within the political space that was available. Feelings of comfort and trust became important elements in the political agenda and the selection of the reviewer. The review made clear that changes were needed and it was taken seriously.

\section{WHAT DID THE GROUP ACHIEVE?}

The Educational Administration Area Group designed a plan of action based upon the Group's self-study during 1993-94. The plan was approved by the Departmental Council on September 30th 1994. A plan for further action included the following:

\section{[1] POLICY}

1.1: "We propose to develop for adoption by Department Council a policy statement on inclusivity in the Educational Administration program that will clarify our meaning of the term, our commitment to it, and contain specific references to the use of inclusive language in our courses and classes. (This will be consistent with existing University policies on Equity and inclusive language.) This policy will be published in our Supplementary Regulations and made reference to in our course outlines."

\section{[2] PROGRAM STRUCTURE AND CONTENT:}

2.1: "We propose to take steps to ensure that inclusivity is fully taken up in the Master's program. This will include infusing issues of inclusivity across the curriculum as well as exploring the place of specific courses and institutes within the required and elective elements of the program."

2.2: "We propose to develop a general reading list and annotated bibliography of material on inclusivity in Educational Administration for our graduate students. This will also be made available to the Clearinghouse on Inclusive Curriculum and updated regularly."

2.3: "We will continue to review our course outlines and to meet and discuss different ways to address inclusivity in our course content. All course outlines are available from the Department Office and feedback on them is welcomed by the Area Group."

\section{[3] PEDAGOGY}

3.1: "We as an Area Group will continue to look for opportunities for both informal and formal professional development in the area of inclusive pedagogy." 


\section{[4] PERSONNEL}

4.: "The Area Group will explore ways to improve this situation. These efforts may include, the recruitment of women and Aboriginal Adjunct Professors who would be able both to teach for the Department and advise thesis students, exploring the possibilities of developing a practicum/ mentorship experience, as well as other forms of collaboration."

The Department made a systematic effort to hire on sessional basis Aboriginal instructors for specific institutes and women conversant with feminist theories.

Further to clause 2.1 of the plan that refers to the development of specific courses and institutes within the required and elective elements of the program saw the development of an outline for a 500 level institute. The designation "institute" is used to describe a course characterized by its interdisciplinary character, team teaching, the use of local and national resource people, and a flexible schedule. These are professional courses open only to students with a first degree. The Institute links social foundations of education and educational administration and aims at exploring how teachers envision and re-envision their roles in a process of change.

The institute is entitled "Controversial Issues in Public School Administration" and is organized around four interconnected themes: (i) the historical role of the school as a politically contested arena and the tensions between the ideal of the "common school," hegemonic principles, forms of discrimination and racism, and resistance and political affirmation from the ethnic communities and the Aboriginal Peoples; (ii) the development of teaching as a profession and the forming of teachers' identity along with ideological as well as policy and administrative changes; (iii) the role of the teacher-the gender issues; (iv) curriculum, political socialization, and the idioms of Canadian citizenship: what is taught and how?

The design calls for these four themes to each cover approximately three sessions. Each theme (on occasion two themes may be merged), will conclude with a case study analysis, usually in the form of a workshop with guest speakers. The course will open with conceptual and theoretical explorations that will be applied to the examination of the issues and close with a revision of those concepts and theories in light of the analysis done during the course. The course is intended to 
encourage students to explore how what is learned at school can become an instrument to be used by students to change social location and how teachers can play transformative roles.

The Institute has not been offered yet. Changes in the Department, mainly the movement of some members of the team to other positions beyond the Department, generated urgencies that compounded the impact of budget cuts. The review of the M.Ed. program at the Faculty level offers now a renewed opportunity for considering the Institute and the recommendations in a new light.

\section{CLOSING THOUGHTS}

Although there is no assessment of the process here described, there were tangible results reflected in the regulations, changes in syllabi, preoccupation with hiring women, a tacit inclusion of gender issues, and more openness toward inclusivity. It is worth noting that in July 1999, the forst occasion since the Review, the Department hired a woman into the area.

The approach had a strong pragmatic tone and it was conditioned by dominant set of assumptions about rights and freedoms. The process revealed the difficulties involved in questioning practices, in unveiling relations of power, the ways of reasoning permeating one's role as professor, in other words disentangling one's own system of ideas. The decentering of the subject did not often happen because by and large most members of the Group were convinced that they spoke out their own reasons, their own words sanctioned by the traditions of the institution (See Popkewitz \& Brennan, 1997). The politics of the process is illustrative of the tendency to place women in administration issues within a nurturing frame of reference, thus recreating a dualistic masculine/feminine construction, rooted in classical humanism and western tradition (See Luke, 1996).

In that sense the questioning of the ethnocentric westernized canon remained hindered by the trap of dualistic thinking around gender construction. The search for evidence reflected the Group's own epistemological foundations, mainly rooted in a philosophy of consciousness that assumes reason can make active subjects aware of their own circumstances. There were little concern among some members of the Group with issues related to the formation of the individual and collective self 
and the role of discursive practices. There was a change along the process in the way the Group located inclusivity issues, in particular, gender issues. They gained a more prominent place and there was some movement toward a reconceptualization of the field. The members' understanding of academic freedom was at the core of the process, although unstated, because it is at the core of the institution itself. The discourse of academic freedom needs to be revisited again and again.

\section{References}

Andersen, M.L. (1987). Changing the curriculum in higher education. Signs, 12. Bruno-Jofré, R. (1996). Academic freedom and equity: Two solitudes? Voice of the Caucus for Women, I(4), October 1996.

Bruno-Jofré, R. \& Andrich, S. (1996). The University of Manitoba clearinghouse for inclusive curriculum: Development and services, 7(1).

Bruno-Jofré R. \& Young, J. (1994). Equity and inclusiveness in a graduate program: A survey of students in educational administration. Unpublished report. Winnipeg, MB: Department of Educational Administration and Foundations, The University of Manitoba.

Chesler, M.A., \& Crowfoot, J.E. (1987) Racism on campus. In W. May (ed.), Ethics and higher education. New York, NY \& Toronto, ON: American Council on Education and Macmillan Publishing Company.

Collins, P.A. (1991). On our own terms: Self-Defined standpoints and curriculum transformation. NWSA Journal, 3(3).

Eisenberg, R. (1988). Defining the terms of academic freedom. Texas Law Review, 66(7).

Gilligan, C. (1982). In a different voice: Psychological theory and women's development. Boston, MA: Harvard University Press.

Harding, S. (1991). Whose science? Whose knowledge? Ithaca, NY: Cornell University Press.

Harvey, D. (1990). The condition of postmodernity, an enquiry into the origins of cultural change, $3 r d$ edition. Great Britain: Cambridge University Press.

House, E. (1994). Policy and productivity in higher education. Educational Researcher, 23(5).

Kasprisin, L. (1991). Educating persons and the social construction of public life. In R. Bruno-Jofré (ed.), Women in higher education: A cross-cultural approach, integrating the grassroots' voice in the quest for change. Western Washington University, Woodring College of Education. 
Leahy, R. (1994). Authenticity: From philosophic concept to literary character. Educational Theory, 44(4).

Luke, C. (1996). Feminist pedagogy theory: Reflections on power and authority. Educational Theory, 46(3).

Lynch, J. (1986). Multicultural education: Principles and practices. London: Routledge and Kegan Paul.

McIntosh, P. (1983). Interactive phases of curriculum revision. Working Paper Series. Wellesley, MA: Wellesley College Center for Research on Women.

Morgan, K.P. (1995). We've come to see the wizard! Revelations of the enlightenment epistemologist. Philosophy of Education. Urbana, IL: Philosophy of Education Society.

Popkewitz, T.S., \& Brennan, M. (1997). Restructuring of social and political theory in education: Foucault and a social epistemology of school practices. Educational Theory, 47(3).

Rabban, D. (1988). Does academic freedom limit faculty autonomy? Texas Law Review, 66(7).

Ross Epp, J. (1994). Women's perceptions of graduate level educational administration programs. The Canadian Journal of Higher Education, 24(2).

Schroeder, P. (1988). Reconstructing American literature: An ongoing process. Ephemera, 1(1).

\section{Appendix 1 - A Summary of Items from the Student Questionnaire}

Section 1: Program Content

1.1: How important do you feel it is that material that involves and affects Women, Aboriginal Peoples, and Minority Ethno-Cultural Groups is included throughout the Educational Administration Masters program?

1.2: How adequately do you feel that the courses you have taken to date have involved the work and experiences of Women, Aboriginal Peoples and Minority Ethno-Cultural Groups?

1.3: How well do you feel the program has allowed you to develop your knowledge of issues of equity and inclusivity in Educational Administration?

1.4: How well do you feel that the program has required all students to become more knowledgeable about equity and inclusivity in Educational Administration? 


\section{Section 2: Teaching methods/Classroom Interactions}

2.1: In your experience of courses in this program how well did you feel the instructors used instructional methods that allowed all students to participate full in the learning process, and ensure that no-one was excluded?

2.2: In your courses to date did you feel that you were encouraged and assisted by the instructor to participate full in all of your classes?

2.3: Aside from the efforts of the instructor, do you feel that other students in the classes you have taken generally encouraged and supported a climate of inclusivity?

2.4: Personally, has it been your experience that other students have created a climate that has enabled you to fully participate in all your classes?

2.5: Has it been your experience that in the classes you have attended inclusive language has been used by the instructor?

2.6: Has it been your experience that in the classes you have attended inclusive language has been requested or required by the instructor in written assignments and classroom discussions?

\section{Section 3: General Departmental Climate}

3.1: Do you feel that our current timetabling arrangements support or inhibit our efforts to develop a program that is readily accessible? (Open-ended)

3.2: Do you feel that the opportunities for informal interaction between students and faculty and students, and students and students support the goal of an inclusive and welcoming intellectual environment? (Open-ended)

\section{Section 4: General Comments}

4.1: Can you give us further feedback on how we might improve our program? (Open-ended)

\section{Notes}

1 The Project embodied the collective history of women working for change at the University. In the Fall of 1989, at the Symposium from Issues to Action, there was an urgent call for curricular change. In 1990, the Caucus for Women, a grassroots body created from the floor of the 1989 Symposium, developed a Task Force Proposal to generate a plan of action which would produce a 
campus favourable equally to women and men. Although the Proposal was approved in principle by the Faculty Association Executive and the Board of Representatives as well as by the President's Advisory Council on Women, it was not accepted by the Administration. However, in 1992, the President's Advisory Council on Women obtained funds from The University of Manitoba Program Development Fund to develop a pilot project on equity in the curriculum. The Project addresses one of the four interrelated issues of the Task Force Proposal of 1990. The Project was housed in the Office of the Vice-President (Academic) and Provost and received strong support from this office. The research for this paper has been supported by the Research Development Fund, The University of Manitoba.

2 The Department in July 1997 merged with the Department of Educational Psychology to form a new Department of Educational Administration, Foundations and Psychology.

3 The paragraphs that refer to academic freedom were taken from BrunoJofré (1996). The paper was read at the panel, Building an Equity Culture: A University-Wide Forum, March 29, 1996, organized by the Faculty of Arts, The Univeristy of Manitoba.

4 Juanita Ross Epp (1994) found, in her analysis of educational administration programs at the graduate level, that $22(18 \%)$ of 123 respondents had a female advisor for their research. Educational administration professors were predominately male $-32 \%$ of the respondents had never had a female professor.

5 The creation of the Clearinghouse for Inclusive Curriculum was proposed originally by the Academic Senior Fellow in March 1993. It was officially announced by the University of Manitoba Libraries in October, 1993. The Clearinghouse is guided by an Advisory Council and has a specialized bibliographer. A network of bibliographers from different disciplines at The University of Manitoba facilitate an effective coordination of the collection process. It has both a material and a virtual dimension. See Bruno-Jofré and Andrich (1996), pp. 66-71.

6 The University of Manitoba, Master of Education, Department of Educational Administration and Foundations, 1996-97, p. 3. 